\title{
A surface lectin associated with flocculation in brewing strains of Saccharomyces cerevisiae
}

\author{
C. S. Shankar† and S. Umesh-Kumar†
}

Author for correspondence: S. Umesh-Kumar. Tel: +91 821 37351. Fax: +91 82127697.

Molecular Biology Unit, Department of Microbiology and Bioengineering, Central Food Technological Research Institute, Mysore570013, India

\begin{abstract}
A cell-wall-surface protein purified from the cells of Saccharomyces cerevisiae NCYC 227 was found to be involved in the non-sexual flocculation of this yeast. This $13 \mathrm{kDa}$ protein was found to bind specifically to mannose. The protein bound to mannans isolated from yeast as well as in situ to intact cells, but only in the presence of calcium ions. The protein, a mannoprotein, formed aggregates as revealed in SDS-PAGE. Urea and higher temperatures prevented protein aggregation, suggesting that the flocculation of $S$. cerevisiae is primarily due to hydrogen bonding between mannan and protein.
\end{abstract}

Keywords: Saccharomyces cerevisiae, flocculation, lectin

\section{INTRODUCTION}

Non-sexual flocculation of Saccharomyces cells represents a specific case of cell adhesion that is of considerable interest in brewing (Rose, 1984). Though described many decades ago, and despite considerable attempts by a number of workers to provide a clear explanation, none has yet been provided for this phenomenon, which is observed in certain brewery strains. Recent evidence establishing cell-surface molecules as components causing flocculation has cast doubt on the earlier views of wort components causing flocculation. The theory that flocculation was due to calcium bridges through phosphodiester linkages in cell mannan or carboxyl groups of proteins has since been replaced by Miki's theory (Miki et al., 1982) of lectin-like interaction of cell-surface mannan and protein of adjoining cells (for review, see Stratford, 1992a). The FLO1 gene sequence described by Teunissen et al. $(1993 \mathrm{a}, \mathrm{b})$ has indicated a very large cell-wall protein of 894 amino acids. This suggested a protein that was glycosyl-phosphatidylinositol-anchored in the membrane, spanned the cell wall, and protruded into the medium. However, the exact nature of the molecules involved in flocculation has not been determined.

When inoculated into a growth medium, flocculating strains of yeast usually remain dispersed and nonflocculent during the exponential phase of growth, with cells flocculating at the stationary phase of growth (Amri et al., 1982). We described (Nagarajan \& Umesh-Kumar,

\footnotetext{
† Present address: Department of Plant Cell Biotechnology, Central Food Technological Research Institute, Mysore-570 013, India.

Abbreviations: ConA, concanavalin A; FITC, fluorescein isothiocyanate.
}

1990), based on the inhibition of flocculation by monovalent $\mathrm{Fab}$ portions of specific antibodies, the identification of flocculation-inducing protein in the cell-wall surfaces of a brewer's yeast, NCYC 227. This paper reports observations on the phenomenon of flocculation based on studies using the purified protein.

\section{METHODS}

Yeast strains. Flocculating strains of $S$. cerevisiae NCYC 227, NCYC 1119, NCYC 1364 and NCYC 625, and non-flocculating strains of $S$. cerevisiae NCYC 431, NCYC 619, NCYC 620 and CS 101 were used. CS 101 was a culture maintained in this laboratory. For some of the experiments, a non-flocculent mutant of $S$. cerevisiae NCYC 227 obtained by ultraviolet radiation was used.

Growth medium. This comprised: glucose, $200 \mathrm{~g}$; $\left(\mathrm{NH}_{4}\right)_{2} \mathrm{SO}_{4}$, $3 \mathrm{~g} ; \mathrm{KH}_{2} \mathrm{PO}_{4}, 3 \mathrm{~g} ; \mathrm{CaCl}_{2}, 0.25 \mathrm{~g} ; \mathrm{MgSO}_{4} .7 \mathrm{H}_{2} \mathrm{O}, 0.25 \mathrm{~g}$; yeast extract, $4 \mathrm{~g}$; distilled water, $1000 \mathrm{ml}$; $\mathrm{pH} 4 \cdot 5$. Measurement of growth and flocculation was as described before (Nagarajan \& Umesh-Kumar, 1990).

Purification of the flocculation protein. The flocculation protein of S. cerevisiae NCYC 227 was identified using antibodies. The antibody preparation was made specific by cross-absorption (Nagarajan \& Umesh-Kumar, 1990) and used for all assays during purification. Wet compressed cells $(100 \mathrm{~g})$ of $S$. cerevisiae NCYC 227 grown to late stationary phase ( $48 \mathrm{~h}$ ) were used for protein extraction. The cells washed in distilled water were suspended in $0.1 \mathrm{M}$ Tris/ $\mathrm{HCl}$ buffer $(\mathrm{pH} 8.0$ ) containing $10 \mathrm{mg}$ lyticase (Sigma) and shaken on a platform shaker. The end-point of extraction was the deflocculation of flocculent cells. The cells were removed by centrifugation and the supernatant was adjusted to $\mathrm{pH} 3.5$ with $1 \mathrm{M} \mathrm{HCl}$. The precipitate obtained after centrifugation was discarded. The supernatant neutralized with $1 \mathrm{M} \mathrm{NaOH}$ (crude extract) was equilibrated to $\mathrm{pH} 8.0$ with $0.1 \mathrm{M}$ Tris/ $\mathrm{HCl}$ buffer by dialysis and subjected to ammonium 
sulphate precipitation at $80 \%$ saturation. The precipitate was dissolved in distilled water, dialysed against the buffer and loaded on a column of DEAE-Sepharose equilibrated with the same buffer. The protein was obtained by step-wise elution at $0 \cdot 2 \mathrm{M} \mathrm{NaCl}$. After dialysis, this fraction was rechromatographed on the same column and gradient elution $(0-0.3 \mathrm{M} \mathrm{NaCl})$ was performed. The fraction eluting around $0.175 \mathrm{M} \mathrm{NaCl}$ was adjusted to $4 \mathrm{M} \mathrm{NaCl}$ by the addition of salt and chromatographed on a phenyl-Sepharose column. Gradient elution $(0-50 \%, v / v$, ethylene glycol) was carried out and the bound protein eluted at $15 \%(\mathrm{v} / \mathrm{v})$ ethylene glycol. This fraction was dialysed against the buffer and applied to a Con-A-Sepharose column. Sequential elution was performed with 0.2 and $0.5 \mathrm{M}$ glucose and mannose, respectively. The protein eluted with $0.5 \mathrm{M}$ mannose was extensively dialysed and lyophilized. Protein concentration was determined by the dye-binding method (Spector, 1978).

Immunological methods. Rabbits were immunized with $0.5 \mathrm{mg}$ of the protein. For immunization, intramuscular injections of the protein in $0.01 \mathrm{M}$ PBS $\left(0.145 \mathrm{M} \mathrm{NaCl}, 0.01 \mathrm{M} \mathrm{NaH}_{2} \mathrm{PO}_{4}\right.$, $\left.0.01 \mathrm{M} \mathrm{Na}_{2} \mathrm{HPO}_{4}, \mathrm{pH} 7 \cdot 2\right)$ mixed with equal volumes of Freund's complete adjuvant were administered on days $0,14,28$ and 42 . The antiserum separated from blood $2 \mathrm{~d}$ after the last injection was subjected to ammonium sulphate precipitation for immunoglobulins. The immunoglobulins dissolved in PBS were extensively dialysed against PBS before use. For some of the tests, monovalent antibody fragments were obtained using papain (Porter, 1959).

Ouchterlony double diffusion. Agarose gels ( $2 \mathrm{~mm}$ thick) were made with $0.6 \%$ agarose in PBS containing $0.1 \%$ sodium azide as preservative. Whole yeast cells $(100 \mu \mathrm{l})$ from the late stationary phase of growth $(48 \mathrm{~h})$, washed with $250 \mathrm{mM}$ EDT $A$, suspended in $0.05 \mathrm{M}$ PBS and adjusted to identical concentrations $\left(\mathrm{OD}_{660}=2 \cdot 0\right)$, were used as antigens. In tests using purified protein or protein extracts, $1 \%(\mathrm{w} / \mathrm{v})$ agarose gels were used. One microgram of protein was loaded in antigen wells for immunodiffusion studies.

Immunofluorescence tests. Flocculent cells of $S$. cerevisiae NCYC 227 dispersed with $250 \mathrm{mM}$ EDTA $\left(\mathrm{OD}_{660}=0.5\right)$ were washed in distilled water and suspended in THS $(0.1 \mathrm{M}$ Tris $/ \mathrm{HCl}, 0.85 \% \mathrm{NaCl}, \mathrm{pH} 8 \cdot 0$ ). Monovalent fragments of the antibody (1:10 dilution in THS) were added to the cells, incubated at $37^{\circ} \mathrm{C}$ for $4 \mathrm{~h}$ and repeatedly washed in THS by centrifugation. Bound antibody was detected indirectly using anti-rabbit goat IgG conjugated to FITC (Sigma; 1:100 dilution). After washing off the unreacted anti-antibody, the cells in THS containing $1 \%(\mathrm{v} / \mathrm{v})$ glycerol were mounted on glass slides for fluorescence microscopy.

In tests involving the non-flocculent mutant, cells of late stationary phase cultures were washed in THS and heat-fixed to the glass slides. The cells were treated with protein in THS containing $50 \mathrm{mM}$ calcium chloride, which had been previously equilibrated to $50^{\circ} \mathrm{C}$ in a water bath. After $60 \mathrm{~min}$ incubation at $30^{\circ} \mathrm{C}$, the slides were washed in THS and bound protein identified by sequential reactions with antibody (1:50 dilution) and anti-rabbit goat $\operatorname{IgG}$ conjugated to FITC as described above.

Controls consisted of cells treated either with BSA or with another lectin, Con-A.

SDSPAGE. This was performed according to the method of Laemmli (1970) using 12\% (w/v) acrylamide gels.

Immunoblotting. The proteins separated by SDS-PAGE were electroeluted onto nitrocellulose membranes (Sigma) for $16 \mathrm{~h}$ at
$30 \mathrm{~V}$ (Towbin et al., 1979). Membranes were blocked at $37^{\circ} \mathrm{C}$ for $2 \mathrm{~h}$ in TTN buffer $(0.01 \mathrm{M}$ Tris, $\mathrm{pH} 8.0,1 \%, \mathrm{v} / \mathrm{v}$, Tween 20 and $0.85 \% \mathrm{NaCl}$ ) containing $20 \%(\mathrm{w} / \mathrm{v})$ non-fat powdered milk (Batteiger et al., 1982). The protein was stained in TTN buffer with specific antibody (1:50 dilution) for $2 \mathrm{~h}$ at $37^{\circ} \mathrm{C}$ and washed four times for $5 \mathrm{~min}$ in TTN buffer. The membranes were incubated in secondary antibody (goat anti-rabbit IgG conjugated to biotin, 1:10000 dilution; Sigma) for $2 \mathrm{~h}$ at $37^{\circ} \mathrm{C}$ and washed four times for $10 \mathrm{~min}$ in TTN buffer. Further incubation of the membrane was carried out in TTN buffer containing avidin-peroxidase conjugate (Sigma; 1:1000 dilution) at $37^{\circ} \mathrm{C}$ for $1 \mathrm{~h}$. These membranes were washed for $10 \mathrm{~min}$ in TTN buffer and bound peroxidase detected using a solution of $50 \mathrm{mM}$ Tris $/ \mathrm{HCl}$ buffer $(\mathrm{pH} \mathrm{7.6)}$ ) containing $0.04 \%$ 4-chloro-1-naphthol and 0.003\% $\mathrm{H}_{2} \mathrm{O}_{2}$.

Indirect ELISA. Yeast mannan (Sigma) was solubilized in $2 \mathrm{M} \mathrm{NaOH}$ and $150 \mu \mathrm{l}$ quantities containing $1 \cdot 0,0 \cdot 5$ and $0 \cdot 1 \mu \mathrm{g}$ of the mannan were immobilized to polyvinyl microtitre plates by drying. After washing the wells in THS, unreacted sites were blocked with $5 \%(\mathrm{w} / \mathrm{v})$ skimmed milk in THS. The wells containing the immobilized yeast mannan received $50 \mu \mathrm{l} 50 \mathrm{mM}$ calcium chloride or THS and $100 \mu \mathrm{l}$ protein at $1: 100$ dilution. The protein solution was equilibrated at $50^{\circ} \mathrm{C}$ in a water bath before addition. After incubation for $4 \mathrm{~h}$ at $30^{\circ} \mathrm{C}$, the wells were washed with THS. Before adding the antibody, calcium in some wells was chelated by addition of $150 \mu 150 \mathrm{mM}$ EDTA (pH 8.0) followed by incubation of the plate at $30^{\circ} \mathrm{C}$ for $30 \mathrm{~min}$ (for this step the other wells received $150 \mu$ l of THS). The bound protein in the washed wells was reacted with $150 \mu$ lof the antibody (1:1000 dilution), and the antibody was detected indirectly by the addition of anti-rabbit goat $\operatorname{IgG}$ conjugated with peroxidase (Sigma). Hydrogen peroxide solution $(0.005 \%)$ containing $0.04 \%$ O-phenylenediamine was used as substrate for the enzyme reaction. The reaction was stopped after $30 \mathrm{~min}$ with $1 \mathrm{M} \mathrm{H}_{2} \mathrm{SO}_{4}$, and the $A_{492}$ read. Controls consisted of uncoated wells, wells coated with $1 \mu \mathrm{g}$ yeast mannan not treated with the protein, and immobilized cells treated with Con A and BSA.

\section{RESULTS AND DISCUSSION}

A flocculation protein can be extracted from flocculating cells of S. cerevisiae NCYC 227 by autoclaving them in $0.2 \mathrm{M}$ citrate buffer, $\mathrm{pH} 7 \cdot 0$ (Nagarajan \& Umesh-Kumar, 1990). The extraction of protein by this procedure was highly variable and in certain extracts the protein could not be identified serologically. The extraction procedure was standardized by shaking the flocculent cells in $0 \cdot 1 \mathrm{M}$ Tris/ $\mathrm{HCl}$ buffer $(\mathrm{pH} 8 \cdot 0)$ containing the enzyme lyticase, and this gave consistent yields. After ammonium sulphate and acid precipitation, this extract was purified by ionexchange, hydrophobic and affinity chromatography. The homogeneity of the protein preparation was established serologically (Fig. 1). Monovalent Fab fragments of the antibody raised against the purified protein inhibited flocculation (as shown previously by Nagarajan \& Umesh-Kumar, 1990), and reaction of the protein on the yeast-cell surface was confirmed by an indirect fluorescent antibody technique (data not shown). Ouchterlony double diffusion studies using the antibodies and cells of various strains of $S$. cerevisiae showed that the protein was present in the flocculating yeast strains NCYC 1119, NCYC 1364 and NCYC 625. It was characteristically absent from nonflocculating yeast strains and a non-flocculating mutant of S. cerevisiae NCYC 227 (Fig. 1b) obtained after ultraviolet 

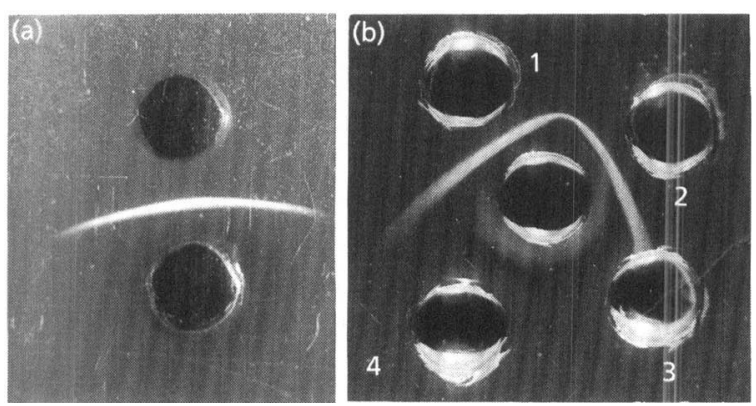

Fig. 1. Ouchterlony reactions of antibodies raised against purified flocculating protein. (a) With purified protein. (b) With flocculent and non-flocculent strains of $S$. cerevisiae. The central well contains the antibody. Peripheral wells contain cells from late stationary phase cultures of (1) NCYC 227; (2) NCYC 1119; (3) non-flocculent mutant of NCYC 227; (4) NCYC 431.

irradiation. This further confirmed the role of the protein in flocculation.

SDS-PAGE of the purified protein preparation treated with $0.1 \%$ SDS and $5 \%$ mercaptoethanol resolved it into a number of proteins of varying molecular masses (Fig. 2a). These proteins were individually separated by electroelution and subjected again to SDS-PAGE. Interestingly these individual proteins also gave rise to different aggregates (Fig. 2b). Though differing in electrophoretic mobility, all the proteins showed complete serological homology with the native protein on reaction with antibody in an Ouchterlony test (Fig. 3). The Western blots showed that the antibody reacted with all aggregates of the purified protein. These aggregates were also seen in the crude yeast extracts of flocculent strains NCYC 1119
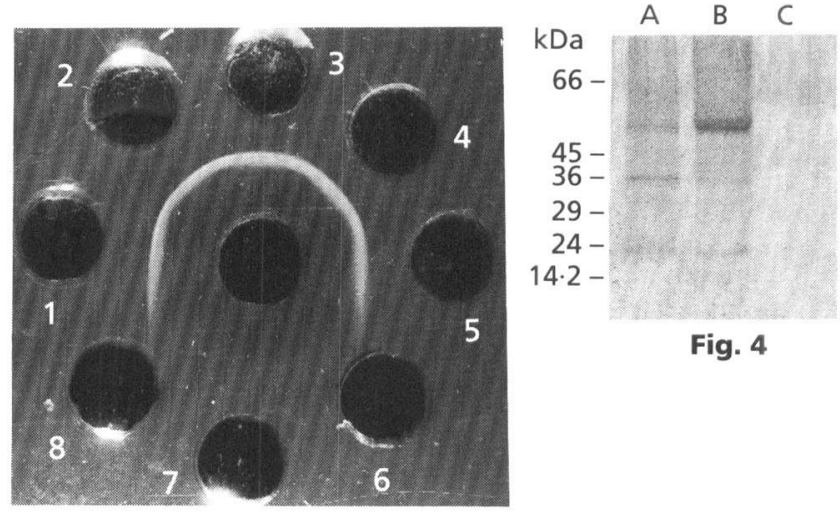

Fig. 4

Fig. 3

Fig. 3. Ouchterlony reactions. Electroeluted proteins from SDSPAGE (Fig. 2a) in $0.1 \mathrm{M} \mathrm{Tris} / \mathrm{HCl}$ buffer $(\mathrm{pH} \mathrm{8.0)}$ were reacted with antibody raised against purified protein (central well). Numbers $1-4$ of the peripheral wells correspond to the proteins of the same number in the SDS-PAGE. Well 5 contains purified native protein. Wells 6-8 contain lyticase extracts of nonflocculent strains of S. cerevisiae NCYC 619, NCYC 620 and CS 101, respectively, after acid and ammonium sulphate precipitations.

Fig. 4. Western blots of crude yeast extracts probed with antibody raised against the purified flocculation protein. Lanes: A, NCYC $227(17.5 \mu \mathrm{g})$; B, NCYC $1119(17.5 \mu \mathrm{g})$; C, NCYC 431 $(25 \cdot 8 \mu \mathrm{g})$.

and NCYC 227 (Fig. 4). The aggregates were not observed in the crude extracts of non-flocculent yeast strain NCYC 431, even when more protein was used for SDS-PAGE

(a)

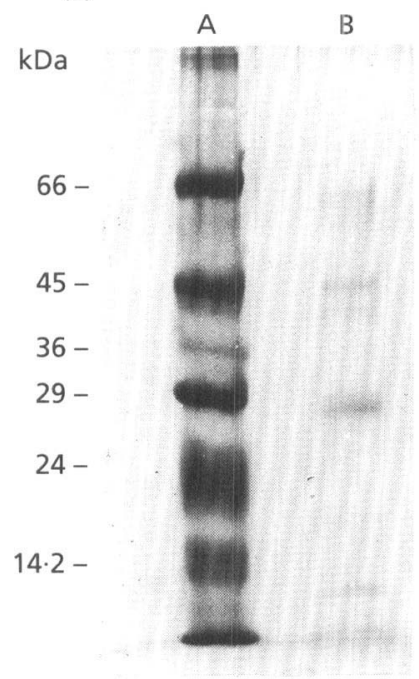

(b)

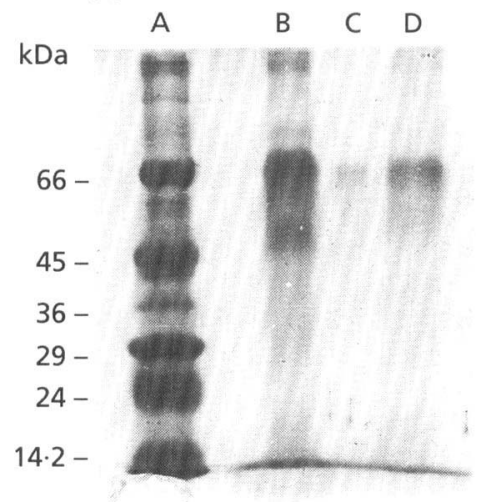

Fig. 2. SDS-PAGE. (a) Purified protein. Lanes: A, molecular mass markers; $B, 15 \mu \mathrm{g}$ purified flocculation protein. (b) Electroeluted and Bio-Gel-eluted purified protein. Lanes: A, molecular mass markers; B and C, $15 \mu \mathrm{g}$ and $2.5 \mu \mathrm{g}$ of the $13 \mathrm{kDa}$ protein electroeluted from SDS-PAGE (Fig. 2a); D, $7.0 \mu \mathrm{g}$ of the $13 \mathrm{kDa}$ protein eluted from the Bio-Gel P60 urea column. 
and more concentrated antibody for Western blots. The higher intensity of the reaction of the protein aggregates in the lane containing protein extracts of NCYC 1119 compared to NCYC 227 suggested a higher flocculating ability of NCYC 1119. Experiments on cultures confirmed the higher flocculation ability of NCYC 1119 over NCYC 227 (data not shown). Dilute solutions of pooled electroeluted proteins resolved into a single protein of $65 \mathrm{kDa}$ on SDS-PAGE (Fig. 2b). A further gel-filtration step using Bio-Gel P100 also resulted in a preparation containing a single $65 \mathrm{kDa}$ protein. Treatment of the protein with $4 \mathrm{M}$ urea followed by gel filtration on a Bio-Gel P60 column equilibrated in $4 \mathrm{M}$ urea $(\mathrm{pH} 8.0$ ) gave a single protein peak of $13 \mathrm{kDa}$. However, samples boiled in $4 \mathrm{M}$ urea and subjected to SDS-PAGE without urea caused reaggregation of the protein (Fig. 2b). Spontaneous aggregation of this protein occurs during SDS-PAGE, and SDS is unable to cause disaggregation. All the data suggested that disulphide linkages were not involved in the protein interaction.

Analysis of the $6 \mathrm{M} \mathrm{HCl}$ hydrolysate of the protein by paper chromatography (Trevalyan et al., 1950) showed that mannose was the only sugar in the protein. This contributed to $5-7 \%$ of the protein as estimated by the phenol/sulphuric acid method (Dubois et al., 1956). When the protein was eluted from Con-A-Sepharose using; mannose the sugar bound strongly to the eluted protein. This binding could, however, be totally reversed by dialysing the eluate at $50^{\circ} \mathrm{C}$. This together with the observation that urea induced deaggregation of the protein suggested the participation of hydrogen bonds in the interaction between sugar and protein as well as in self-aggregation of the protein.

Yeast mannan (Sigma) immobilized in the wells of the microtitre plates bound the protein only in the presence of calcium. Removal of calcium with EDTA dislodged the protein. Glucose, fructose, xylose and galactose polymers did not react with the protein, even in the presence of calcium. Of the divalent ions tested, magnesium, cobalt and manganese (used as chlorides) gave shift binding as evidenced by colour intensities in ELISA, whereas monovalent ions did not promote binding (no reaction). These results suggest a steric specificity of the protein for mannose. In the absence of calcium, the terminal residues of the mannan probably bind rather loosely to protein, resulting in their removal during the washing steps of ELISA.

In conclusion, the cells of the brewer's yeast $S$. cerevisiae, during the late exponential phase, produce a cell- surface mannoprotein of molecular mass $13 \mathrm{kDa}$ that specifically binds to cell-surface mannan of adjoining cells primarily by hydrogen bonding: this causes flocculation to occur. In this reaction, the role of calcium is probably to maintain the configuration of the binding site. Recently, the mannose structures involved in flocculation have been shown to be the mannan outer-chain side branches (Stratford, 1992b). That the protein described here reacts with cell-surface mannan is shown by its reaction with the non-flocculent mutant of S. cerevisiae NCYC 227 (Fig. 5).

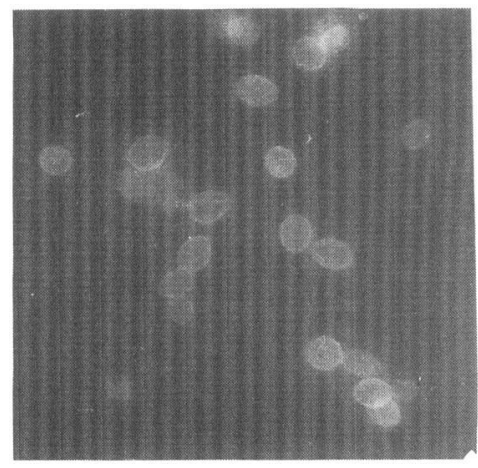

Fig. 5. Surface reaction of the protein on fixed cells of the nonflocculent mutant of S. cerevisiae NCYC 227 . The bound protein was detected using antibody and anti-rabbit goat IgG conjugated with FITC.

Although Holmberg (1978) has previously described a $13 \mathrm{kDa}$ protein involved in the flocculation of $S$. cerevisiae and Teixeira et al. (1989) and Saito et al. (1990) reported the isolation of $37 \mathrm{kDa}$ proteins from flocculent strains of Kluyveromyces marxianus and Hansenula anomala respectively, this is probably the first report on the isolation of active lectins associated with flocculation.

\section{ACKNOWLEDGEMENTS}

The authors are grateful to L. Nagarajan, Research fellow for technical help. We thank Dr Richard Joseph, Head of the Department, for suggestions in the work, and the Director of the Institute for facilities. This work was supported by CSIR, New Delhi, through a Junior Research Fellowship to C.S.S.

\section{REFERENCES}

Amri, M. A., Bonaly, R., Duteurtre, B. \& Moll, M. (1982). Yeast flocculation: influence of nutritional factors on cell wall composition. J Gen Micrabiol 128, 2001-2009.

Batteiger, B., Newhall, W. J. \& Jones, R. B. (1982). The use of Tween 20 as a blocking agent in the immunological detection of proteins transferred to nitrocellulose membranes. J Immunol Methods 55, 297-307.

Dubois, M., Gilles, K. A., Hamilton, J. K., Rebers, P. A. \& Smith, F. (1956). Colorimetric method for determination of sugars and related substances. Anal Chem 28, 350-356.

Holmberg, S. (1978). Isolation and characterisation of a polypeptide absent from non-flocculent mutants of Saccharomyces cerevisiae. Carlsberg Res Commun 43, 401-413.

Laemmli, U. K. (1970). Cleavage of structural proteins during the assembly of the head of bacteriophage T4. Nature 227, 680-685.

Miki, B. L. A., Poon, N. H., James, A. P. \& Seligy, V. L. (1982). Possible mechanism for flocculation interactions governed by gene FL01 in Saccharomyces cerevisiae. J Bacteriol 150, 878-889.

Nagarajan, L. \& Umesh-Kumar, S. (1990). Antigenic studies on flocculating brewer's yeast, Saccharomyces cerevisiae NCYC 227. J Gen Microbiol 136, 1747-1751.

Porter, R. R. (1959). The hydrolysis of rabbit $\gamma$-globulin and antibodies with crystalline papain. Biochem J 73, 119-126.

Rose, A. H. (1984). Physiology of cell aggregation: flocculation by 
Saccharomyces cerevisiae as a model system. In Microbial Adhesion and Aggregation, pp. 323-335. Edited by K. C. Marshall. Berlin: Springer-Verlag.

Saito, K., Sato, S., Shimoi, H., Hiuji, H. \& Tadenuma, M. (1990). Flocculation mechanism in Hansenula anomala J224. Agric Biol Chem 54, 1425-1432.

Spector, T. (1978). Refinement of the coomassie blue method of protein quantitation. Anal Biochem 86, 142-146.

Stratford, M. (1992a). Yeast flocculation: a new perspective. $A d v$ Microb Physiol 33, 1-71.

Stratford, M. (1992b). Yeast flocculation: receptor definition by $m n n$ mutants and concanavalin A. Yeast 8, 635-645.

Teixeira, J., Goncalves, M. H. J., Gama, F. M., Moradas-Ferreira, P. \& Moto, M. (1989). Partial characterisation of cell wall from a flocculent strain of Kluyveromyces marxianus. Biotechnol Lett 11, $579-582$.
Teunissen, A. W. R. H., van den Berg, J. A. \& Steensma, H. Y. (1993a). Physical localization of the flocculation gene FL01 on chromosome I of Saccharomyces cerevisiae. Yeast 9, 1-10.

Teunissen, A. W. R. H., Holub, E., van der Hucht, J., van den Berg, J. A. \& Steensma, H. Y. (1993b). Sequence of the open reading frame of the FL01 gene from Saccharomyces cerevisiae. Yeast $\mathbf{9}$, 423-427.

Towbin, H., Staehelin, T. \& Gordon, J. (1979). Electrophoretic transfer of proteins from polyacrylamide gels to nitrocellulose sheets. Procedure and some applications. Proc Natl Acad Sci USA 76, 4350-4354.

Trevalyan, W. E., Proctor, D. P. \& Harrison, J. S. (1950). Detection of sugars on paper chromatograms. Nature 166, 444-445.

Received 2 August 1993; revised 10 October 1993; accepted 24 November 1993. 